\title{
Climate Change Adaptation Among Smallholder Farmers in Rural Ghana
}

\section{Peter Asare-Nuamah and Athanasius Fonteh Amungwa}

\section{Contents}

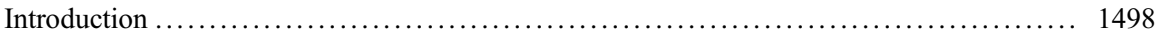

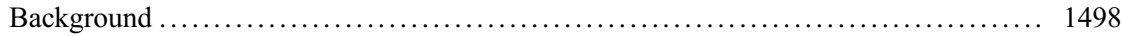

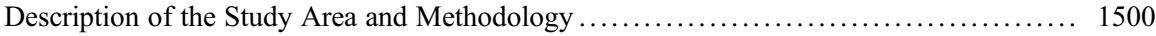

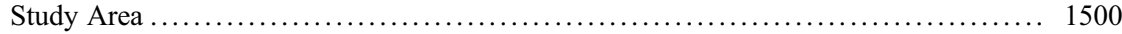

Research Methods ................................................... 1500

Results and Discussion ................................................. 1504

Adaptation Strategies Employed by Smallholder Farmers ........................ 1504

Predictors of Adaptation Strategies ........................................ 1506

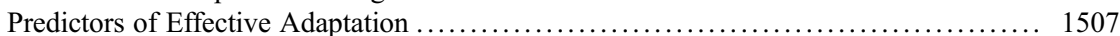

Conclusion and Recommendations ......................................... 1509

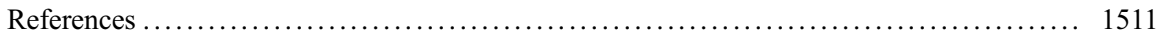

\section{Abstract}

Climate change has the potential to disrupt sustainable development initiatives, particularly in developing economies. A substantial body of literature reveals that developing economies are vulnerable to climate change, due to high dependency on climate-sensitive sectors, such as agriculture. In Ghana, a growing body of literature has revealed multiple adaptation strategies adopted by smallholder farmers to respond to and reduce climate change impacts. However, there is a dearth of literature on the effectiveness of adaptation strategies. This chapter explores the adaptation strategies of smallholder farmers and analyzed the predictors of effective adaptation. Through the technique of simple random

P. Asare-Nuamah $(\bowtie)$

Institute of Governance, Humanities and Social Science, Pan African University, Soa, Cameroon

School of Sustainable Development, University of Environment and Sustainable Development, Somanya, Eastern Region, Ghana
A. F. Amungwa
Department of Sociology and Anthropology, Faculty of Social and Management Sciences,
University of Buea, Buea, Cameroon 
sampling, 378 smallholder farmers were selected, and data was collected using a questionnaire survey. Descriptive and inferential statistics were performed using the SPSS software. The findings indicate that smallholder farmers adopt multiple adaptation strategies to reduce the impact of climate change. In addition, it is revealed that marital status, years of farming experience, knowledge of climate change, and education are significant predictors of adaptation. Moreover, the chapter found that marital status, weedicide application, change in staple food consumption, and planting of early-maturing crops are good predictors of effective adaptation. The chapter recommends the need to intensify adaptation strategies through agricultural extension programs and interventions that improve rural food security and livelihood. In addition, the chapter recommends strengthening the capacity of farmer organizations and rural institutions, particularly agricultural extension and advisory services.

\section{Keywords}

Climate change $\cdot$ Climate change adaptation $\cdot$ Effective adaptation $\cdot$ Smallholder farmers $\cdot$ Ghana

\section{Introduction}

\section{Background}

Climate change adaptation is defined as the adjustment in a system to respond to, recover from, and exploit opportunities, to reduce the impact of climate change. Adaptation has gained center stage in global development debates and discourse (IPCC 2018; World Bank 2018). The heightened attention of adaptation stems from the fact that climate change affects every component of the earth's system, particularly the biosphere and essential life-dependent resources (IPCC 2018). More importantly, climate change affects agriculture, thereby increasing the vulnerability of developing countries, whose economies are largely dependent on climate-sensitive sectors, including agriculture (AGRA 2014; IPCC 2018). According to the Intergovernmental Panel on Climate Change (IPCC) $(2014,2018)$, adaptation strategies are very important in developing economies in Africa and Asia, as the impact of climate change is already felt in extreme in these regions. For instance, climaterelated disasters, such as floods and droughts, are predominant and extreme in Africa and Asia. Moreover, El Nino Southern Oscillation (ENSO) has been reported in Southern and West Africa, with prolonged dry season in Ghana (see Hirons et al. 2018; IPCC 2014, 2018). Consequently, a large body of literature has focused on examining the adaptation strategies adopted particularly by smallholder farmers to respond to these changes, with little or no attention on the effectiveness of adaptation as a conduit for food security and livelihood, which this chapter seeks to address. Dankelman (2010) asserts that adaptation strategies, particularly in developing countries, are ineffective and unsustainable, as they are practiced in a resource- 
constrained environment, which calls for the need to examine effective adaptation strategies employed by smallholder farmers to enhance their food security and livelihood.

According to the European Environment Agency (EEA 2013), effective adaptation requires holistic, concrete, and process-based measures and approaches, whereas the German Development Agency (GIZ 2014) and IPCC (2007, 2014) argue that effective adaptation strategies have the potential to increase adaptive capacity and offset the negative impact of climate change, by decreasing sensitivity and exposure to climate change. Globally, farmers have adopted adaptation strategies to reduce vulnerability and respond to climate shocks and stresses, such as erratic rainfall, high temperature, flood, drought, and pests, among others (IPCC 2007, 2014, 2018). Adaptation strategies may be self-induced or externally planned; proactive, reactive, or concurrent; planned or spontaneous; and tactical or strategic. In addition, they may occur at different scales, such as local, regional, or international; by agents of adaptation including but not limited to individuals, communities, governments, the private sector, and non-governmental/civil society organizations (Antwi-Agyei et al. 2014a; Bryant et al. 2000; Smit et al. 2000; Smit and Skinner 2002; IPCC 2014). To ensure an effective adaptation, it is essential for adaptation agents to adopt planned adaptation behaviors, which are typical of disaster preparedness, as well as ensure effective response and recovery to disasters (World Bank 2018b).

A growing body of literature has revealed that farmers have adapted to climate change through multiple on-/off-farm adaptation strategies such as climate-smart agricultural practices, to enhance their livelihood and food security, which depend largely on the environment (Antwi-Agyei et al. 2014a; Gyampoh et al. 2009; Pearce and Ford 2015; Yaro et al. 2014). In Ghana, for instance, crop and livelihood diversification; pesticide, weedicide, and fertilizer application; water harvesting; and planting of early-maturing and drought-resistant crops have been reported in the literature (Antwi-Agyei et al. 2014a, b; Fosu-Mensah et al. 2012; Gyampoh et al. 2009; Osumanu et al. 2017; Yaro 2013a, b; Yaro et al. 2014). Nevertheless, Sarpong and Anyidoho (2012) argue that the adaptation strategies in Ghana are not effective due to poor policy environment, whereas Connolly-Boutin and Smit (2016) and the IPCC (2014) argue that poor natural resource management, low adaptive capacity, and poverty make the adaptation strategies ineffective in Africa.

According to the GIZ (2014) and Turner et al. (2003), entitlement, access, and endowment influence the adaptive capacity to climate change. This corroborates the assertion that the assets owned, used, and/or available to communities and households enable them to adapt to climate change (IPCC 2007, 2014). Similarly, studies have demonstrated that adaptation is dependent on multiple socioeconomic factors, such as age, gender, years of farming experience, assets, level of education, household size, and technology (Adu et al. 2018; Fosu-Mensah et al. 2012; Lopez-Ridaura et al. 2018). The present study aims to achieve the following objectives: explore adaptation strategies of smallholder famers and predict factors that promote adaptation and effective adaptation. The rest of the paper presents the methods, results, and conclusion. 


\section{Description of the Study Area and Methodology}

\section{Study Area}

The study was conducted in the Adansi North District, located in the Ashanti Region of Ghana on longitude $1.50 \mathrm{~W}$, latitude $1.4 \mathrm{~N}$ and longitude $1.5 \mathrm{~W}$, latitude $6.30 \mathrm{~N}$. It covers about $853.63 \mathrm{~km}^{2}$, which is equivalent to $4.7 \%$ of the surface area of the region. It also has a total population of about 107,109, with 54,036 (50.5\%) females and 53,055 (49.5\%) males (GSS 2010, 2014). The dependency ratio in the district is high, with males found to be more dependent than females (GSS 2014). Located in the semi-equatorial climate, the district experiences high temperature and rainfall, with a mean rainfall of $1250 \mathrm{~mm}$ to $1750 \mathrm{~mm}$ and temperature of $27^{\circ} \mathrm{C}$. The district has bi-modal rainfall patterns, comprising of major and minor rainy seasons. February is the hottest month in the district, and agriculture is the major economic activity, employing about $77 \%$ of the labor force, followed by services (15\%) and manufacturing (8\%) (GSS 2014). The district has rich ochrosols, which favor agriculture and forest vegetation. The major food crops produced here include cassava, plantain, cocoyam, maize, yam, and cash crops, such as cocoa and oil palm. As a rural district, poverty, low income, and lack of access to basic socioeconomic assets are dominant in the district (GSS 2014).

\section{Research Methods}

\section{Study Site Selection and Sampling Method}

A total of 15 communities from 7 operational areas were selected via multistage sampling techniques comprising of cluster and simple random sampling. The district has 15 operational areas which served as the clusters from which 7 were randomly selected. A sample of 378 farm household heads was randomly selected using the district census data as the sample frame. Krejcie and Morgan's (1970) statistical table for sample size selection led to the selection of 378 respondents from the household population of 23,863 .

\section{Data Sources and Collection Methods}

The chapter used quantitative primary data. Data collection lasted for 6 months, starting from April to September 2018. Prior to data collection, the Institutional Review Committee of the Pan African University, Cameroon, approved the study. The data collection instrument was questionnaire survey. The questionnaire was divided into sections to collect data on the respondents' demographic characteristics, access to essential assets, and adaptation strategies.

\section{Data Analysis}

Primary data was analyzed using the Statistical Package for Social Sciences (SPSS) version 20. Data cleaning was performed through frequency analysis to identify the missing data. Preliminary analyses, such as outliers and normality tests, were 
Table 1 Variables description and coding

\begin{tabular}{l|l}
\hline Variable description & Variable coding \\
\hline Dependent variable & \\
Have you adapted to climate change? & Yes $=1$ \\
& No $=0$ \\
\hline Independent variables & Male $=1$ \\
Sex & Female $=0$ \\
Age & Years (Number) \\
Household size & Number \\
Education & Yes $=1$ \\
& No $=0$ \\
Marital status & Married $=1$ \\
& Else $=0$ \\
\hline Access to land & Yes $=1$ \\
Access to extension & No $=0$ \\
& Yes $=1$ \\
Access to market & No $=0$ \\
Knowledge of climate change & Yes $=1$ \\
& No $=0$ \\
Access to technology (e.g. phone) & Yes $=1$ \\
Farming experience & No $=0$ \\
& Yes $=1$ \\
& No $=0$ \\
& Yes $=1$ \\
No $=0$
\end{tabular}

Source: Fieldwork, 2018

conducted using box and scatter plots as well as line graphs (Pallant 2016). Two binary logistic regression models were specified for the analysis. The first binary logistic regression model explored factors that predicted the respondents' climate change adaptation strategies. The dependent variable in the first model was adaptation that was operationalized as whether or not a respondent has adapted to climate change using any of the strategies available to them. The independent variables comprised of categorical and continuous variables, such as age, sex, household size, farming experience, marital status, access to land, access to technology (phone), access to market, extension service, and knowledge of climate change. Table 1 presents the variable coding and description.

The use of the preliminary regression model without the predictor variables resulted in an overall percentage of $59.2 \%$ in terms of whether respondents have adapted or not, which served as a baseline for comparison with the regression model that included predictor variables (Pallant 2016). The Omnibus Tests of Model Coefficient, which determines the "goodness of fit" of the regression model resulted in a significance level of $0.006(p<0.05)$. The Omnibus goodness of fit test also resulted in a chi-squared value of 26.193, with 11 degrees of freedom. In addition, the Hosmer-Lemeshow goodness-of-fit test resulted in a chi-squared value of 6.701 
with 8 degrees of freedom and a significant value of 0.569. Pallant (2016) asserts that for the Hosmer-Lemeshow test to be significant, the significant value must exceed 0.05 . The significant value of 0.569 exceeded 0.05 , which is indicative of the goodness of fit of the model. The Cox and Snell R-squared and Nagelkerke Rsquared indicated that the predictor variables account for $26.7 \%$ and $29.1 \%$ of variation in the dependent variable, respectively. In addition, the percentage accuracy in classification (PAC) table (Pallant 2016) resulted in an overall percentage of $62.3 \%$, which exceeded the initial value of $59.2 \%$. This chapter computed for the sensitivity of the model. According to Pallant (2016), the sensitivity of the model is defined as the percentage of the respondents who have or have not adapted to climate change, which has been accurately identified by the model. It is computed by dividing the number of cases predicted by the total number predicted and multiplied by 100 (Pallant 2016). The positive predictive (true positive) value indicates the percentage of respondents who have adapted to climate change and has been accurately identified by the model. The positive predictive value is $57.5 \%$. Conversely, the negative predictive value (true negative) is the percentage of respondents who have not adapted and has been accurately identified by the model. The computation resulted in $61.8 \%$ for the negative predictive value.

In the second model, a binary logistic regression analysis was conducted to understand the adaptation strategies that effectively improve the respondents' food security and livelihood. The dependent variable was "whether or not adaptation strategies effectively enhance food security and livelihood of respondents." The independent variables consisted of categorical variables of 24 different adaptation strategies adopted by the respondents. In addition, the predictors of adaptation from the first model were included in the second model. Table 2 presents the coding and description of variables used in the second regression model.

The initial regression model without the predictor variables resulted in an overall percentage of $88.9 \%$ in terms of whether or not adaptation enhances food security and livelihood. The Omnibus Test of Model Coefficient resulted in a significance level of $0.018(p<0.05)$, with a chi-squared value of 45.858 and 28 degrees of freedom. The Hosmer-Lemeshow goodness-of-fit test resulted in a chi-squared value of 7.085 with 8 degrees of freedom, at a significant value of 0.527 . The Cox \& Snell R-squared and Nagelkerke R-squared values were 0.114 and 0.227 respectively, indicating that the predictor variables account for $11.4 \%$ and $22.7 \%$ of the variation in the dependent variable, respectively.

The PAC table resulted in an overall percentage of $89.4 \%$, exceeding the initial value of $88.9 \%$. In addition, the chapter computed for the sensitivity of the model, which is the percentage of the respondents accurately identified by the model as those who indicated that adaptation enhances or does not enhance food security and livelihood. Sensitivity is computed by dividing the number of cases predicted by the total number predicted and multiplied by 100 (Pallant 2016). The positive predictive value (true positive) indicates the percentage of respondents who indicated that adaptation effectively enhances food security and livelihood. The positive predictive value was $89.8 \%$. The negative predictive value (true negatives) is, however, the 
Table 2 Variables description and coding

\begin{tabular}{|c|c|}
\hline Variable description & Variable coding \\
\hline $\begin{array}{l}\text { Dependent variable } \\
\text { Does adaptation effectively enhance food } \\
\text { security and livelihood? }\end{array}$ & $\begin{array}{l}\text { Yes }=1 \\
\text { No }=0\end{array}$ \\
\hline $\begin{array}{l}\text { Independent variables } \\
\text { Migration }\end{array}$ & Yes $=1$ \\
\hline Fertilizer application & $\begin{array}{l}\text { No }=0 \\
\text { Yes }=1 \\
\text { No }=0\end{array}$ \\
\hline So Klin application & $\begin{array}{l}\text { Yes }=1 \\
\text { No }=0\end{array}$ \\
\hline Education & $\begin{array}{l}\text { Yes }=1 \\
\text { No }=0\end{array}$ \\
\hline Marital status & $\begin{array}{l}\text { Married = } 1 \\
\text { Else }=0\end{array}$ \\
\hline Delayed farming & $\begin{array}{l}\text { Yes }=1 \\
\text { No }=0\end{array}$ \\
\hline Pesticides application & $\begin{array}{l}\text { Yes }=1 \\
\text { No }=0\end{array}$ \\
\hline Cocoa pollination & $\begin{array}{l}\text { Yes }=1 \\
\text { No }=0\end{array}$ \\
\hline Reduced number of diets & $\begin{array}{l}\text { Yes }=1 \\
\text { No }=0\end{array}$ \\
\hline Reduced diet size & $\begin{array}{l}\text { Yes }=1 \\
\text { No }=0\end{array}$ \\
\hline Change staple diet & $\begin{array}{l}\text { Yes }=1 \\
\text { No }=0\end{array}$ \\
\hline Irrigation (hand/machine) & $\begin{array}{l}\text { Yes }=1 \\
\text { No }=0\end{array}$ \\
\hline Extension services & $\begin{array}{l}\text { Yes }=1 \\
\text { No }=0\end{array}$ \\
\hline Early maturing crops & $\begin{array}{l}\text { Yes }=1 \\
\text { No }=0\end{array}$ \\
\hline Improved crops varieties & $\begin{array}{l}\text { Yes }=1 \\
\text { No }=0\end{array}$ \\
\hline Livelihood diversification & Yes $=1$ \\
\hline Knowledge of climate change & $\begin{array}{l}\text { No }=0 \\
\text { Yes }=1\end{array}$ \\
\hline & $\begin{array}{l}\text { No }=0 \\
\text { Yes }=1\end{array}$ \\
\hline Help from family and friends & $\begin{array}{l}\text { Yes }=1 \\
\text { No }=0\end{array}$ \\
\hline Farming experience (years) & $\begin{array}{l}\text { Yes }=1 \\
\text { No }=0\end{array}$ \\
\hline Crop diversification & $\begin{array}{l}\text { Yes }=1 \\
\text { No }=0\end{array}$ \\
\hline Multiple cropping season & $\begin{array}{l}\text { Yes }=1 \\
\text { No }=0\end{array}$ \\
\hline Weedicides application & $\begin{array}{l}\text { Yes }=1 \\
\text { No }=0\end{array}$ \\
\hline Cocoa spraying & Yes $=1$ \\
\hline Farm expansion & $\begin{array}{l}\text { No }=0 \\
\text { Yes }=1\end{array}$ \\
\hline
\end{tabular}


Table 2 (continued)

\begin{tabular}{l|l}
\hline Variable description & Variable coding \\
\hline \multirow{3}{*}{ Farm Based Organizations } & No $=0$ \\
& Yes $=1$ \\
Chicken droppings application & No $=0$ \\
& Yes $=1$ \\
Drought resistant crops & No $=0$ \\
& Yes $=1$ \\
Change in livestock & No 0 \\
& Yes $=1$ \\
\hline
\end{tabular}

Source: Fieldwork, 2018

percentage of respondents who were accurately identified by the model to have indicated that adaptation does not enhance their food security and livelihood. The negative predictive value was $66.7 \%$.

\section{Results and Discussion}

\section{Adaptation Strategies Employed by Smallholder Farmers}

The respondents in the study have adopted multiple adaptation strategies as presented in Table 3. The dominant adaptation strategy of the respondents is crop diversification, as reported by $93.4 \%$ of respondents. Antwi-Agyei et al. (2014a) similarly reported that majority of smallholder farmers in the Bongo District in the Upper East Region of Ghana practice crop diversification, as a response to climate change. Crop diversification is a traditional farming practice where multiple crops are planted on the same plot of land. The system enables farmers to harvest different crops throughout the year, thereby increasing food security. The practice may be influenced by the different maturity periods of crops, nutrient requirement, and demand on the market. Majority of the respondents have resorted to delay farming (70.1\%), fertilizer application (68\%), planting of early-maturing crops $(42.1 \%)$, improved crop varieties (33.9\%), and multiple-cropping season (51.3\%). About $51.1 \%$ of the respondents reported of extension services. Studies have reported that extension services enable farmers to adapt to climate change through the transfer of knowledge and emerging farm practices (Boyaci and Yildiz 2016; Morrison and Sarris 2007).

Aside from extension services, the Government of Ghana's agricultural interventions, such as cocoa spraying and cocoa pollination, were also reported by $42.1 \%$ and $34.7 \%$ of the respondents, respectively, as adaptation strategies. It is interesting to note that some farmers are turning to the application of chicken dropping $(17.5 \%)$ as an alternative to chemical fertilizer, which they hinted to be expensive. Unique to the findings of this chapter is the application of "So-Klin," a washing detergent used 
Table 3 Respondents' adaptation strategies

\begin{tabular}{l|l|l}
\hline Indicators & $(\%)$ & $\mathrm{N}(378)$ \\
\hline Migration & 8.3 & 33 \\
\hline Fertilizer application & 68.0 & 257 \\
\hline So Klin application & 44.4 & 168 \\
\hline Planting of early-maturing crops & 42.1 & 159 \\
\hline Improved crop varieties & 33.9 & 128 \\
\hline Livelihood diversification & 57.4 & 217 \\
\hline Help from family and friends & 40.5 & 153 \\
\hline Crop diversification & 93.4 & 353 \\
\hline Delayed farming & 70.1 & 265 \\
\hline Multiple-cropping seasons & 51.3 & 194 \\
\hline Pesticide application & 34.7 & 131 \\
\hline Weedicide application & 43.2 & 164 \\
\hline Cocoa pollination & 34.7 & 131 \\
\hline Cocoa spraying & 42.1 & 159 \\
\hline Reduced number of diets & 57.4 & 217 \\
\hline Reduced meal size & 66.4 & 251 \\
\hline Change in diets/staple food & 52.4 & 198 \\
\hline Irrigation (hand/machine) & 26.7 & 101 \\
\hline Extension services & 51.1 & 193 \\
\hline Change in livestock & 35.4 & 134 \\
\hline Planting of drought-resistant crops & 18.3 & 69 \\
\hline Farm expansion & 38.4 & 145 \\
\hline Joining in farm-based organizations & 3.7 & 14 \\
\hline Chicken dropping application & 17.5 & 66 \\
\hline So & &
\end{tabular}

Source: Fieldwork 2018

to control fall armyworm invasion. Some respondents indicated that they use both "So-Klin" and pesticides to control fall armyworms. It is reported that fall armyworms cause significant crop loss, particularly maize, sorghum, and millet (FAO 2018; Wild 2017). In Ghana, about 1.4 million ha of maize and cowpea have been destroyed by fall armyworms, whereas about 6400 ha of cocoa farms have been invaded (African Union 2017; Mpofu 2017; OCHA 2017). Loss of maize from fall armyworms in Africa has been estimated at US $\$ 3$ billion (African Union 2017). About $57.4 \%$ of the respondents have diversified their livelihood. Livelihood diversification has been reported in by Antwi-Agyei et al. (2014a, b) as a conduit to climate change adaptation. Table 3 demonstrates that the respondents have resorted to diet-related adaptation strategies as a response to climate change. For instance, respondents reported reduction in meal size $(66.4 \%)$, change in diet/staple food $(52.4 \%)$, and reduction in the number of diets $(57.4 \%)$, which are consistent with the literature (Giannini et al. 2016; Quaye 2008). Other adaptation strategies include help from family and friends (40.5\%), pesticide (34.7\%) and weedicide (43.2\%) 
application, change in livestock (35.3\%), farm expansion (38.4\%), irrigation (26.7\%), and planting of drought-resistant crops (18.3\%).

\section{Predictors of Adaptation Strategies}

The output of the binary logistic regression analysis is presented in Table 4 . The beta $(\beta)$ values represent the change in the logit of the outcome variable (the log odds ratio) with a unit change in the predictor variable. The $\beta$ value for years of farming experience, for instance, is -0.616 , which indicates that an increase in the experience of a respondent by 1 year will result in a decrease in the adaptation of the respondents to climate change by 0.616 . Put differently, the finding indicates that as the years of experience of a respondent increase, there is less likelihood that the respondent will not adapt to climate change. An increase in education increases climate change adaptation by 0.581 , whereas access to market and marital status also increase adaptation by 0.178 and 0.583 , respectively. Respondents with knowledge of climate change are more likely to adapt to climate change by 1.715 . These findings are consistent with the literature (Osumanu et al. 2017; Tessema et al. 2018). For instance, as the level of education increases, farmers are likely to increase their climate change knowledge and become more concerned of the need to adapt. In addition, education increases farmers' knowledge of available and emerging adaptation strategies, including technology and climate-smart agriculture.

The Wald statistic with a chi-squared distribution demonstrates whether or not the $\beta$ values for predictor variables are significantly different from zero (Mensah 2008). From Table 4, household size, for instance, has a Wald statistic of 2.171, which is significantly different from 0 . However, the contribution of household size to the model is statistically insignificant at a $p$-value of 0.141 (thus, $p<0.05$ ). From the model, years of experience, education, marital status, and knowledge of climate

Table 4 Binary logistic regression of the predictors of climate change adaptation

\begin{tabular}{l|r|l|l|l}
\hline Variables & $\beta$ & Wald & Significance & $\operatorname{Exp}(\beta)$ \\
\hline Sex & -0.112 & 0.176 & 0.675 & 0.894 \\
\hline Age & 0.008 & 0.728 & 0.393 & 1.008 \\
\hline Household size & 0.037 & 2.171 & 0.141 & 1.037 \\
\hline Experience & -0.616 & 3.752 & $0.050^{*}$ & 0.540 \\
\hline Education & 0.581 & 4.738 & $0.030^{*}$ & 1.789 \\
\hline Marital status & 0.583 & 4.085 & $0.043^{*}$ & 1.792 \\
\hline Access to land & -0.520 & 1.582 & 0.208 & 0.594 \\
\hline Access to technology & -0.443 & 1.712 & 0.191 & 0.642 \\
\hline Access to extension services & -0.028 & 0.012 & 0.914 & 0.973 \\
\hline Market & 0.178 & 0.451 & 0.502 & 1.195 \\
\hline Climate change knowledge & 1.715 & 4.739 & $0.029^{*}$ & 5.559 \\
\hline Constant & -2.310 & 5.263 & 0.022 & 0.099
\end{tabular}

Source: Computed from fieldwork 2018 
change have Wald statistics of 3.752, 4.738, 4.085, and 4.739, respectively, which are statistically significant at $p$-values of $0.050,0.030,0.043$, and 0.029 , respectively. Marital status, for instance, plays a significant role in climate change adaptation, as it promotes pool of resources. In addition, married household heads are more likely to adapt due to their responsibility to feed their families and cater for their wards. Studies have revealed that the farming experience and knowledge of climate change significantly influence climate change adaptation (Osumanu et al. 2017; Tessema et al. 2018).

Another important statistic presented in Table 4 is the $\operatorname{Exp}(\beta)$. These values, which are the odd ratios of the predictor variables, show the odds of the outcome variable occurring as a result of a unit change in the predictor variable. Statistically, the odd of an event is the probability of that event occurring divided by the inverse or the probability of that event not occurring (Mensah 2008). $\operatorname{Exp}(\beta)$ values greater than 1 means that an increase in the predictor variables results in an increase in the odds of the outcome variable, whereas $\operatorname{Exp}(\beta)$ values less than 1 show an inverse relationship between the odds of the outcome and the predictor variable. For instance, knowledge of climate change has $\operatorname{Exp}(\beta)$ value of 5.559, which indicates that there is a positive relationship between adaptation and knowledge of climate change. As such, it can be interpreted that increasing the knowledge of climate change of a respondent increases the respondent's adaptation to climate change. Table 4 demonstrates that age, household size, education, marital status, and market increase adaptation to climate change, whereas sex, experience, access to land, technology, and extension service reduce adaptation to climate change. It can be concluded from the model that years of experience, education, marital status, and knowledge of climate change are significant predictors of climate change adaptation, which is consistent with the previous studies (Osumanu et al. 2017; Tessema et al. 2018). The equation of the model can be written as Logit(Adaptation) $=-2.310$ (Constant) $-0.112 *$ Sex $+0.008 *$ Age $+0.037 *$ Household size $-0.616 *$ Experience + $0.581 *$ Education $+0.583 *$ Marital status $-0.520 *$ Land $-0.443 *$ Technology $0.028 *$ Extension $+0.178 *$ Market $+1.715 *$ Climate change knowledge.

\section{Predictors of Effective Adaptation}

Table 5 presents the output of the binary logistic regression estimation. The $\beta$ value is the change in the logit of the outcome variable (the log odds ratio) as a result of a unit change in a the predictor variable. The $\beta$ values indicate that improved crop varieties, weedicide application, and change in staple food consumption, for instance, increase food security and livelihood by $1.130,1.315$, and 1.333 , respectively. It can be asserted that improved crop varieties, weedicide application, and change in staple food consumption have positive relationships with food security and livelihood. The more a respondent adopts these adaptation strategies, the more likely food security and livelihood of the respondent will improve. Other adaptation strategies, such as cocoa spraying, multiple-cropping season, and drought-resistant crops, are positively related to food security and livelihood as a unit increase in these strategies 
Table 5 Binary logistic regression of the predictors of effective adaptation

\begin{tabular}{l|r|l|l|l}
\hline Variables & \multicolumn{1}{|l}{$\beta$} & Wald & Significance & $\operatorname{Exp}(\beta)$ \\
\hline Migration & 0.305 & 0.121 & 0.728 & 1.357 \\
\hline Fertilizer application & 0.016 & 0.001 & 0.973 & 1.016 \\
\hline So Klin application & 0.418 & 0.586 & 0.451 & 1.519 \\
\hline Planting of early-maturing crops & -1.325 & 3.918 & $0.048^{*}$ & 0.266 \\
\hline Improved crop varieties & 1.130 & 2.374 & 0.123 & 3.095 \\
\hline Livelihood diversification & -0.705 & 2.212 & 0.145 & 0.494 \\
\hline Help from family and friends & 0.221 & 0.193 & 0.660 & 1.248 \\
\hline Crop diversification & 0.246 & 0.077 & 0.782 & 1.279 \\
\hline Delayed farming & -0.655 & 1.664 & 0.197 & 0.520 \\
\hline Multiple-cropping season & 0.531 & 0.922 & 0.337 & 1.701 \\
\hline Pesticide application & -1.117 & 2.138 & 0.144 & 0.327 \\
\hline Weedicide application & 1.315 & 3.444 & $0.500^{*}$ & 3.724 \\
\hline Cocoa pollination & 0.200 & 0.068 & 0.795 & 1.222 \\
\hline Cocoa spraying & 0.474 & 0.504 & 0.478 & 1.607 \\
\hline Reduced number of diets & -1.156 & 3.432 & 0.064 & 0.315 \\
\hline Reduce meal size & -0.357 & 0.292 & 0.589 & 0.700 \\
\hline Change in staple food consumption & 1.333 & 7.111 & $0.008^{*}$ & 3.793 \\
\hline Irrigation & -0.308 & 0.238 & 0.626 & 0.735 \\
\hline Extension services & 0.176 & 0.160 & 0.689 & 1.192 \\
\hline Change in livestock & -0.843 & 2.735 & 0.098 & 0.430 \\
\hline Planting of drought-resistant crops & 0.884 & 1.429 & 0.232 & 2.420 \\
\hline Farm expansion & -0.008 & 0.000 & 0.987 & 0.992 \\
\hline Joining in farm-based organization & -1.145 & 1.506 & 0.220 & 0.318 \\
\hline Chicken dropping application & -0.822 & 3.465 & 0.063 & 0.440 \\
\hline Years of farming experience & 0.154 & 0.100 & 0.752 & 1.166 \\
\hline Education & -0.365 & 0.692 & 0.405 & 0.694 \\
\hline Marital status & 0.749 & 3.582 & $0.503^{*}$ & 2.116 \\
\hline Knowledge of climate change & -18.547 & 0.901 & 0.998 & 0.001 \\
\hline Constant & 20.933 & 2.385 & 0.998 & 1.681 \\
\hline Source Con & & &
\end{tabular}

Source: Computed from fieldwork 2018

improves food security and livelihood by a margin of $0.474,0.531$, and 0.884 , respectively. Among the predictors of adaptation, years of farming experience (0.154) and marital status (0.749) have a positive relationship with food security and livelihood.

The Wald statistic demonstrates whether or not the $\beta$ values for predictor variables are significantly different from zero (Mensah 2008). Predictor variables such as marital status, chicken dropping application, planting of early-maturing crops, livelihood diversification, pesticide application, weedicide application, reduction in the number of diets, and change in staple food consumption, for instance, are significantly different from zero with Wald statistics of 3.582, 3.465, 3.918, 2.212, $2.138,3.444,3.432$, and 7.111 , respectively. The significance column in the table 
presents the level of significance of the predictor variables in predicting effective adaptation. The model indicates that effective adaptation is significantly predicted by planting early-maturing crops (0.048), weedicide application (0.050), change in staple food consumption (0.008), and marital status $(0.053)$. The $\operatorname{Exp}(\beta)$ values are the odds of the outcome variable occurring as a result of a unit change in the predictor variable. Statistically, the odd of an event is the probability of the event occurring divided by the inverse or the probability of that event not occurring (Mensah 2008). $\operatorname{Exp}(\beta)$ values greater than 1 indicate that an increase in the predictor variables result in an increase in the odds of the outcome variable, whereas $\operatorname{Exp}(\beta)$ values less than 1 show an inverse relationship between the odds of the outcome and the predictor variable.

For instance, planting of drought-resistance crops, change in staple food consumption, weedicide application, and improved crop varieties have $\operatorname{Exp}(\beta)$ values greater than 1 which indicates a positive correlation between effective adaptation (food security and livelihood) and these predictors. Marital status (0.001), planting of early-maturing crops, $(0.266)$, and pesticide application $(0.372)$, for instance, have $\operatorname{Exp}(\beta)$ values less than 1 which indicates an inverse or negative relationship with effective adaptation (food security and livelihood). It can be summed up from the model that planting of early-maturing crops, weedicide application, change in staple crop consumption, and marital status significantly predict effective adaptation (food security and livelihood). The equation of the model can be written as Logit(EffectiveAdaptation) $=20.933$ (Constant) $+0.035^{*}$ Migration + $0.016 *$ Fertilizer application $+0.418 *$ So Klin application $-1.325 *$ Planting of earlymaturing crops $+1.130 *$ Improved crop varieties $-0.705^{*}$ Livelihood diversification + $0.221 *$ Help from family and friends $+0.246 *$ Crop diversification $-0.655^{*}$ Delayed farming $+0.531 *$ Multiple-cropping season $-1.117 *$ Pesticide application + $1.315 *$ Weedicide application $+0.2008 *$ Cocoa pollination $+0.474 *$ Cocoa spraying $-1.156 *$ Reduced number of diets $-0.357 *$ Reduced meal size $+1.333^{*}$ Change in staple food $-0.308 *$ Irrigation $+0.176 *$ Extension $-0.843 *$ Change in livestock $+0.884 *$ Planting of drought-resistant crops $-0.008 *$ Farm expansion $-1.145^{*}$ Joining in farm-based organization $-0.822 *$ Chicken dropping application $+0.154 *$ Experience $-0.365 *$ Education $+0.749 *$ Marital status $-18.547^{*}$ Climate change knowledge.

\section{Conclusion and Recommendations}

Ghana's ability to promote food security, livelihood, and rural and pro-poor economic development is largely dependent on agriculture and hence smallholder farmers who constitute the bulk of the labor force in Ghana and contribute about $80 \%$ of the food produced. The agriculture sector, in particular, and smallholder farmers, in general, are vulnerable to climate change, due to subsistence and climatedependent nature of agriculture and low adaptive capacity of smallholder farmers, in addition to high poverty and less access to essential assets. Nevertheless, smallholder farmers in Ghana are adapting to climate change through multiple self-induced and 
externally supported adaptation strategies. This chapter, which sought to explore smallholder famers' adaptation and examine the predictors of adaptation and effective adaptation, found that smallholder farmers in the rural Adansi North District of Ghana use multiple on-/off-farm and diet-based adaptation strategies to respond to climate change. The chapter also found that marital status, years of farming experience, education, and knowledge of climate change significantly influence adaptation, whereas marital status, weedicide application, change in diet/staple food, and planting of early-maturing crops significantly enhance effective adaptation (food security and livelihood) of smallholder farmers.

While farmers are adapting to climate change, most adaptation strategies of smallholder farmers do not necessarily enhance their food security and livelihood, which may be due to the resource-constrained environment and low adaptive capacity. As such, it is imperative that social intervention programs and policies that promote resource distribution and access must be strengthened, particularly in rural communities, to increase smallholder farmers' access to essential socioeconomic assets, thereby increasing adaptive capacity, improving adaptation strategies, and reducing climate change impacts. In addition, mass education of farmers on climate change must be intensified to improve climate change knowledge/perception, reduce misconceptions associated with climate change, and ensure effective adaptation, as farmers' climate change perception strongly influences climate change adaptation. Farm-based organizations can play a significant role in climate change education and must be promoted particularly in rural communities. Moreover, local institutions, particularly those that provide extension and advisory services, must be intensified and resourced with technology, personnel, and infrastructure to provide services that enable farmers to adapt effectively to climate change through skills and knowledge transfer.

While this chapter limited its geographic scope to only the Adansi North District, the chapter could do better if it covered a wider geographic scope across different ecological zones in Ghana, to deepen the understanding of how different communities are adapting to climate change, which is very important for fit-forpurpose climate change policies. Hence, further studies must consider larger population with a wider geographic location to better understand climate change adaptation in Ghana. In addition, a combination of quantitative and qualitative data on climate change adaptation can greatly improve an understanding of climate change and advance the debate on adaptation. This chapter used only quantitative data, but future studies must go further to include qualitative lived experiences of smallholder farmers. Nevertheless, the chapter has made significant contributions to climate change discourse and has provided insights, with the potential to shape climate change policies in Ghana, in particular, and Africa, in general.

Acknowledgments The authors are grateful to the African Union for funding this study through the Pan African University PhD research grant awarded to the first author. 


\section{References}

Adu DT, Kuwornu JKM, Anim-Somuah H, Sasaki N (2018) Application of livelihood vulnerability index in assessing smallholder maize farming households' vulnerability to climate change in Brong-Ahafo region of Ghana. Kasetsart J Soc Sci 39(1):22-32. https://doi.org/10.1016/j.kjss. 2017.06.009

African Union (2017) Phytosanitary news bulletin: fall armyworms storm Africa. African Union, Yaounde

AGRA (2014) Africa agriculture status report 2014: climate change and smallholder agriculture in sub-Saharan Africa. AGRA, Nairobi. Retrieved from www.agra.org

Antwi-Agyei P, Dougill AJ, Stringer LC (2014a) Barriers to climate change adaptation: evidence from northeast Ghana in the context of a systematic literature review. Clim Dev 7:297-309. https://doi.org/10.1080/17565529.2014.951013

Antwi-Agyei P, Stringer LC, Dougill AJ (2014b) Livelihood adaptations to climate variability: insights from farming households in Ghana. Reg Environ Chang 14(4):1615-1626. https://doi. org/10.1007/s10113-014-0597-9

Boyaci M, Yildiz O (2016) An overview of agricultural extension services in Turkey. Bulgarian J Agr Sci 22(1):151-157

Bryant C, Smit B, Brklacich M, Johnston T, Smithers J, Chiotti Q, Singh B (2000) Adaptation in Canadian agriculture to climatic variability and change. Clim Chang 45:181-201

Connolly-Boutin L, Smit B (2016) Climate change, food security, and livelihoods in sub-Saharan Africa. Reg Environ Chang 16:385-399. https://doi.org/10.1007/s10113-015-0761-x

Dankelman I (2010) Gender and climate change: an introduction. Routledge, London

EEA (2013) Adaptation in Europe: addressing risks and opportunities from climate change in the context of socioeconomic developments. EEA, Copenhagen. Retrieved from http://www.eea. europa.eu/publications/adaptation-in-europe

FAO (2018) Briefing note on FAO actions on fall armyworm in Africa. FAO, Rome. Retrieved from http://www.fao.org/3/BS183E/bs183e.pdf

Fosu-Mensah BY, Vlek PL, MacCarthy D (2012) Farmers' perception and adaptation to climate change: a case study of Sekyedumase district in Ghana. Environ Sustain Dev 8(3):1-13. https:// doi.org/10.1007/s10668-012-9339-7

Giannini A, Krishnamurthy PK, Cousin R, Labidi N, Choularton RJ (2016) Climate risk and food security in Mali : a historical perspective on adaptation. Earth's Future 5:144-157. https://doi. org/10.1002/eft 2.176

GIZ (2014) The vulnerability sourcebook: concepts and guidelines for standardized vulnerability assessment. GIZ, Eschborn

GSS (2010) Population and housing census 2010. GSS, Accra

GSS (2014) 2010 population and housing census: district analytical report, Adansi North District. GSS, Accra

Gyampoh BA, Amisah S, Idinoba M, Nkem JN (2009) Using traditional knowledge to cope with climate change in rural Ghana. Unasylva 60(231/232):70-74. https://doi.org/10.1016/j. foodchem.2011.01.039

Hirons M, Boyd E, McDermott C, Asare R, Morel A, Mason J, ... Norris K (2018) Understanding climate resilience in Ghanaian cocoa communities - advancing a biocultural perspective. J Rural Stud 63(August):120-129. https://doi.org/10.1016/j.jrurstud.2018.08.010

IPCC (2007) Climate change 2007: impacts, adaptation and vulnerability. Contribution of working group II to the fourth assessment report of the intergovernmental panel on climate change. Cambridge University Press, Cambridge, MA

IPCC (2014) Climate change 2014: synthesis report. Contributions of working groups I, II and III to the fifth assessment report of the intergovernmental panel on climate change. IPCC, Geneva 
IPCC (2018) IPCC special report on the impacts of global warming of $1.5^{\circ} \mathrm{C}$ - summary for policy makers. IPCC, Incheon. Retrieved from http://www.ipcc.ch/report/sr15/

Krejcie RV, Morgan DW (1970) Determining sample size for research activities. Educ Psychol Meas 30:607-610. https://doi.org/10.1177/001316447003000308

Lopez-Ridaura S, Frelat R, van Wijk MT, Valbuena D, Krupnik TJ, Jat ML (2018) Climate smart agriculture, farm household typologies and food security: an ex-ante assessment from Eastern India. Agric Syst 159:57-68. https://doi.org/10.1016/j.agsy.2017.09.007

Mensah J (2008) Religious transnationalism among Ghanaian immigrants in Toronto: a binary logistic regression analysis. Can Geogr 52(3):309-330. https://doi.org/10.1111/j.1541-0064. 2008.00215.x

Morrison J, Sarris A (2007) WTO rules for agriculture. FAO, Rome

Mpofu V (2017) The foreign invader costing African farmers $\$ 3$ billion. Retrieved September 15, 2017, from http://www.irinnews.org/news/2017/09/14/foreign-invader-costing-african-farmers3-billion?utm_source=IRIN+-+the+inside+story+on+emergencies \&utm campaign $=860 \overline{\mathrm{d}} \mathrm{c} 2 \mathrm{c} 80 \mathrm{~d}-\mathrm{RSS}$ EMAIL_CAMPAIGN_ENGLISH_AFRICA\&utm medium $=$ email\&utm_term $=0 \_\mathrm{d} 84 \mathrm{4} 2 \mathrm{~d} 98289-860 \mathrm{dc} 2 \mathrm{c} 80 \mathrm{~d}-7546666$

OCHA (2017) West and Central Africa: weekly regional humanitarian snapshot. New York. Retrieved from https://reliefweb.int/sites/reliefweb.int/files/resources/ExternalWeekly2430October2017.pdf

Osumanu IK, Aniah P, Yelfaanibe A (2017) Determinants of adaptive capacity to climate change among smallholder rural households in the Bongo District, Ghana. Ghana J Dev Stud 14 (2):142-163. https://doi.org/10.4314/gjds.v14i2.8

Pallant J (2016) SPSS survival manual - a step by step guide to data analysis using SPSS program, 6th edn. McGraw-Hill, London

Pearce LBT, Ford JD (2015) Systematic review approaches for climate change adaptation research. Reg Environ Chang 15:755-769. https://doi.org/10.1007/s10113-014-0708-7

Quaye W (2008) Food security situation in northern Ghana, coping strategies and related constraints. J Agric Res 3(5):334-342. https://doi.org/10.1126/science.1185383

Sarpong DB, Anyidoho NA (2012) Climate change and agricultural policy processes in Ghana (Working paper 045). Future Agricultures, Accra

Smit B, Skinner M (2002) Adaptation options in agriculture to climate change: a typology. Mitig Adapt Strateg Glob Chang 7:85-114

Smit B, Burton I, Klein RJ, Wandel J (2000) An anatomy of adaptation to climate change and variability. Climate Change 45:223-251

Tessema YA, Joerin J, Patt A (2018) Factors affecting smallholder farmers' adaptation to climate change through non-technological adjustments. Environ Dev 25:33-42. https://doi.org/10.1016/ j.envdev.2017.11.001

Turner RB, Kasperson RE, Matson PA, McCarthy JJ, Corell RW, Christensen L, ... Schiller A (2003) A framework for vulnerability analysis in sustainability science. Natl Acad Sci 100 (14):8074-8079. https://doi.org/10.11764/j.issn.1672-1926.2014.S1.0091

Wild S (2017) Invasive pest hits Africa. Nature 509:13-14. https://doi.org/10.1038/509015a

World Bank (2018) 2025 targets to step up climate action. World Bank, Washington, DC. Retrieved from http://pubdocs.worldbank.org/en/368601543772742074/2025-Targets-to-Step-Up-Cli mate-Action.pdf

World Bank (2018b) Adaptation and resilience: action plan. World Bank, Washington, DC. Retrieved from www.worldbank.org/climatechange

Yaro JA (2013a) Building resilience and reducing vulnerability to climate change: implications for food security in Ghana. Friedrich Ebert Stiftung, Accra

Yaro JA (2013b) The perception of and adaptation to climate variability/change in Ghana by smallscale and commercial farmers. Reg Environ Chang 13(6):1259. https://doi.org/10.1007/s10113013-0443-5

Yaro JA, Teye J, Bawakyillenuo S (2014) Local institutions and adaptive capacity to climate change/variability in the northern savannah of Ghana. Clim Dev 7(3):37-41. https://doi.org/ $10.1080 / 17565529.2014 .951018$ 
Open Access This chapter is licensed under the terms of the Creative Commons Attribution 4.0 International License (http://creativecommons.org/licenses/by/4.0/), which permits use, sharing, adaptation, distribution and reproduction in any medium or format, as long as you give appropriate credit to the original author(s) and the source, provide a link to the Creative Commons license and indicate if changes were made.

The images or other third party material in this chapter are included in the chapter's Creative Commons license, unless indicated otherwise in a credit line to the material. If material is not included in the chapter's Creative Commons license and your intended use is not permitted by statutory regulation or exceeds the permitted use, you will need to obtain permission directly from the copyright holder.

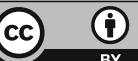

